\title{
Study on mechanical properties of a bimetallic composite produced by explosion welding under incremental plastic deformation
}

\author{
D. A. Konovalov ${ }^{\dagger}$ I. A. Veretennikova \\ ${ }^{\dagger}$ satterkein@yandex.ru \\ Institute of Engineering Science Ural Branch of RAS, 34 Komsomolskaya st., Yekaterinburg, 620049, Russia
}

\begin{abstract}
The paper presents the results of studies on the changes in mechanical characteristics of a "08Cr18Ni10Ti-steel 10" bimetal strip subjected to incremental plastic deformation by rolling in 5 passes with a reduction of about $10 \%$ per pass. The bimetal was obtained by explosion welding. Tensile tests of bimetallic samples after each rolling pass were carried out. It is demonstrated that the relative reduction of individual layers is changed non-proportionally to the magnitude of the relative reduction of the bimetallic strip as a whole. The weld zone obtained as a result of explosion welding is separately considered. To define the size of the weld zone, the distribution of the values of microhardness in the cross sections of the bimetallic strip after each rolling pass was used. The size of the weld zone decreased from $0.4 \mathrm{~mm}$ to $0.1 \mathrm{~mm}$ after 5 passes. The values of conventional yield strength for the weld zone and the individual layers of the bimetal were obtained by kinetic indentation with the processing of loading curves by an original method developed in the IES UB RAS. The value of conventional yield strength of the bimetal after explosion welding is higher than that of each material individually. With further plastic strain, the strength properties of the stack do not increase as intensively as the strength properties of stainless steel. A mixture rule can be used in order to calculate the theoretical conventional yield strength for the bimetal after explosion welding.
\end{abstract}

Keywords: bimetal, conventional yield strength, weld zone, plastic deformation, explosion welding.

УДК: 539.389 .1

\section{Исследование механических свойств биметалла, полученного сваркой взрывом, при поэтапной пластической деформации}

\author{
Коновалов Д. А. ${ }^{\dagger}$, Веретенникова И. А. \\ Институт машиноведения УрО РАН, ул. Комсомольская, 34, Екатеринбург, 620049, Россия
}

В работе приведены результаты исследования механических свойств сварного соединения биметаллической полосы «08Х18Н10Т-сталь 10» после поэтапной деформации прокаткой в 5 проходов с обжатием 10\% за проход. Биметалл был получен сваркой взрывом. Осуществлены испытания на растяжение биметаллических образцов после каждого прохода прокатки. Было показано, что деформация составляющих биметалла при прокатке не пропорциональна деформации полосы в целом. Особое внимание уделено сварной зоне, получаемой в результате сварки взрывом. На основании распределения значений микротвердости на поперечных шлифах в области сварной границы биметалла «08Х18Н10Т-сталь 10» были определены размеры сварной зоны. Ширина сварной зоны уменьшается с 0,4 мм до 0,1 мм за 5 проходов прокатки. Получены значения условного предела текучести для сварной зоны и отдельных составляющих биметалла в зависимости от обжатия с помощью метода кинетического индентирования с обработкой кривых нагружения по оригинальной методике, разработанной в ИМАШ УрО РАН. Значение условного предела текучести биметалла после сварки взрывом выше значений для каждого материала в отдельности. После дополнительной пластической значение условного предела текучести для биметалла существенно ниже значений для упрочненной нержавеющей стали 08X18Н10Т. В целях расчета теоретического условного предела текучести для биметалла после сварки взрывом можно применять правило смеси. Правило смеси может быть применено для теоретического расчета условного предела текучести для биметаллов, полученных сваркой взрывом.

Ключевые слова: биметалл, условный предел текучести, сварная зона, пластическая деформация, сварка взрывом. 


\section{Introduction}

At the present stage of industry and science development, great attention is paid to the use of bimetallic materials produced by explosion welding (EW) in the manufacture of structures, machines and mechanisms [1,2]. Optimum conditions for producing high-quality bimetals by EW are currently known [3]. One of the main lines of further research is the study on the behavior of a bimetal in subsequent processing and operation. The problem of using bimetals, which hampers its wide application, is the risk of fracture in the weld zone under subsequent deformation. The weld zone consists of the weld boundary and adjacent areas of initial metals, which are significantly strengthened by EW.

When designing machines and mechanisms, it is necessary to know the values characterizing the strength and deformation properties of the materials. Conventional yield strength and tensile strength, which can be obtained by means of standard mechanical tests, are traditionally used as characterizing parameters in a standard engineering design [4]. The characteristics of a bimetal and the effect of the weld zone on the mechanical characteristics of the entire finished package are determined by means of standard testing methods. However, it is technically complicated to study the change in the mechanical properties of the bimetal constituents and the weld zone by these methods. Nondestructive testing methods are applied in this case. One of these methods is the kinetic indentation, which allows local mechanical properties of bimetal constituents to be determined without manufacturing many samples. Previous studies $[5,6]$ reported the development, testing and adaptation a technique that makes it possible to obtain a strain hardening curve using the test results obtained from impressing three conical indenters with different cone angles.

In this paper, conventional yield strength is used as a comparative parameter. Conventional yield strength is an important material characteristic, which corresponds to the stress causing permanent strain of $0.2 \%$ [4]. Working stresses in parts must be below the conventional yield strength. When this value is exceeded, the structure undergoes irreversible changes in its linear dimensions, and this leads to an inadmissible change in the shape of the product and may cause its total failure.

The aim of this study is to estimate the changes of the conventional yield strength of a bimetallic strip as a whole, its weld zone and individual layers under incremental plastic deformation. The resulting data facilitates understanding the deformation behavior of individual constituents in the bimetal and their contribution to the deformation behavior of the entire package during plastic deformation. The determination of the actual mechanical properties of weld zones enables one to predict the operability and durability of bimetallic constructions more reliably. This study employs standard experimental methods of tensile testing, the authors' technique and analytical formulas, and this has allowed us to evaluate the strength characteristics in terms of different approaches. A bimetallic composite constituted by stainless steel and carbon steel is selected as the test material. The selection of this material is stipulated by its wide application in industry and also by its usability for conducting model experiments [7-8]. Incremental rolling is chosen as the method of plastic deformation.

\section{Materials}

Samples of steel 10 and $08 \mathrm{Cr} 18 \mathrm{Ni} 10 \mathrm{Ti}$ austenitic steel, joined by EW into a bimetallic strip, were examined. EW was carried out in Uraltekhnoproekt LLC (Ekaterinburg) under process conditions typical for the industrial production of blanks of this type. In the initial state, the thicknesses of the blanks were $3.9 \mathrm{~mm}$ for steel $10,1.9 \mathrm{~mm}$ for the $08 \mathrm{Cr} 18 \mathrm{Ni} 10 \mathrm{Ti}$ steel and $5.8 \mathrm{~mm}$ for the bimetal. It was reported in [9-10] that, as a result of EW, a well-formed joint with a characteristic wavy boundary was obtained in the " $08 \mathrm{Cr} 18 \mathrm{Ni} 10 \mathrm{Ti}$-steel 10 " material.

\section{Experimental techniques and methods of analysis}

The experiments were performed using the equipment of the Plastometriya collective use center affiliated to the IES UB RAS (Ekaterinburg).

Rolling was carried out at room temperature on a DuoQuarto 250 laboratory rolling mill. Samples of the bimetal, as well as single-layer steels 10 and $08 \mathrm{Cr} 18 \mathrm{Ni10Ti}$, were rolled. Samples sized $15 \times 200 \mathrm{~mm}$ were cut for rolling. The rolling speed was $0.3 \mathrm{~m} / \mathrm{s}$. Relative percentage reduction $\eta$ was defined as the ratio $\eta=\left(h_{0}-h_{1}\right) / h_{0} \cdot 100 \%$, where $h_{0}$ and $h_{1}$ are the thicknesses of the strip before and after rolling, respectively [11].

The mechanical tensile tests of the samples were carried out at room temperature on an Instron-8801 multi-purpose servo-hydraulic testing machine.

The microhardness distribution was investigated using a NanoTriboindentor TI 950 complex, where the hardness is determined by the Oliver-Pharr method.

Kinetic indentation experiments were carried out using diamond pyramidal indenters, with the angles between the faces of $90^{\circ}, 120^{\circ}$ and $136^{\circ}$, on a Zwick/Roell Z2.5 precision test machine. The maximum load in all the tests was equal to $100 \mathrm{~N}$. The indentation was performed on the surface of the cross section of the bimetallic strip positioning the indenter in central parts of individual bimetal constituents. Five indentions were made for each indenter type into each of the three parts found in the composite (steel 10, steel 08Cr18Ni10 Ti and the weld zone), 45 indentions in total. The distance between adjacent indentations was $2 \mathrm{~mm}$. The original method, developed in the IES UB RAS and described in [5], allows one to get the strain hardening curve using the indentation diagrams. A three-parameter power law dependence for approximation of the strain hardening curve was used in the method [5]. The three-parameter function more accurately describes the strain hardening curves of metals than the two-parameter function, as it has more degrees of freedom. Since the approximation involves three parameters, three independent experiments are needed to determine them. The conventional yield strength is calculated by the formula $\sigma_{0.2}=\sigma_{0}(1+0.002 a)^{b}$, where $\sigma_{0}, a$ and $b$ are approximation parameters. The values of $\sigma_{0}, a$ and $b$ are defined by the method [5] using the experiments on indenting three indenters with different angles. 


\section{Results and discussion}

Table 1 presents the thickness $(t)$ of the bimetal and its individual layers, as well as the reduction of the entire stack and each individual layer after each rolling pass. In the case of plastic deformation, the relative reduction of individual layers has changed non-proportionally to the magnitude of the relative reduction of the bimetallic strip as a whole. Initially, the layer of steel 10 was subjected to the largest strain. After the first pass, the reduction of the layer of steel 10 is $37.3 \%$ versus $4.7 \%$ for the $08 \mathrm{Cr} 18 \mathrm{Ni} 10 \mathrm{Ti}$ steel layer. In the second pass, there is practically no reduction of the $08 \mathrm{Cr} 18 \mathrm{Ni} 10 \mathrm{Ti}$ steel layer, whereas steel 10 continues to deform. This fact is explained by the lower strength of steel 10 in case of small values of strain. In the third and fourth passes, the value of the relative reduction of the layers is approximately the same, since the hardening of steel 10 occurred in the previous passes. In the fifth pass, the 08Cr18Ni10Ti steel layer undergoes the largest strain, and the layer of steel 10 is strained only slightly.

Microhardness measurements were made along the transverse areas of the samples in the weld zones and the adjacent metal zones of each layer with a maximal load of $50 \mathrm{mN}$ and an indentation step of $0.1 \mathrm{~mm}$ [9]. The width of the measurement area in the cross direction was $4 \mathrm{~mm}$ in each case. A great body of data obtained from the measurements has allowed us to determine the size of the weld zone, in which the mechanical properties are different from the properties of the bimetal layers, and to estimate the degree of its strain hardening. Fig. S1 (Supplementary Information) shows the microhardness maps for the cross section of the bimetal after EW and after 3 passes of rolling. The physical weld boundary is determined optically, then the dimensions of the adjacent hardened areas are evaluated from the side of the 10 and $08 \mathrm{Cr} 18 \mathrm{Ni} 10 \mathrm{Ti}$ steels, and the width of the weld zone for the bimetal is calculated. The microhardness values of the sections of 10 and $08 \mathrm{Cr} 18 \mathrm{Ni10 \textrm {Ti }}$ steels, which are far from the near-weld zone, are equal to $2-3 \mathrm{GPa}$ and 3.5-4.5 GPa, respectively. After the first, second and third passes, an increase to $3.5 \mathrm{GPa}$ in the microhardness values over the volume of the layer of steel 10 is observed, and local hardening areas with the value of microhardness up to $4 \mathrm{GPa}$ appear. Initially, the microhardness of the $08 \mathrm{Cr} 18 \mathrm{Ni} 10 \mathrm{Ti}$ steel layer ranges between 3.5 and $4.5 \mathrm{GPa}$; with further rolling, it evenly increases throughout the whole volume, and after the fifth pass it is in the range from 5.5 to $6 \mathrm{GPa}$. Moreover, in 08Cr18Ni10Ti steel, after the last pass there are local sections with a microhardness of about $6.5 \mathrm{GPa}$.
The microhardness of steel 10 in the area bordering the weld boundary varies from 3 to $5 \mathrm{GPa}$. In $08 \mathrm{Cr} 18 \mathrm{Ni} 10 \mathrm{Ti}$ steel, microhardness values in the weld boundary region range between 4.5 and $5 \mathrm{GPa}$. Based on these data, dimensions of the intermediate weld zone have been obtained (see Table 1). Fig. S1 clearly shows that the size of the zone of the hardened $08 \mathrm{Cr} 18 \mathrm{Ni10Ti}$ steel is several times larger than that of the hardened zone of steel 10. After the first and second passes, there is an insignificant increase in the microhardness values in the selected weld zone. After the fourth pass, there is no difference in the mechanical properties of the weld zone and the $08 \mathrm{Cr} 18 \mathrm{Ni10Ti}$ steel layer at the weld boundary. This is not observed for steel 10; a narrow band of hardened material with mechanical properties different from those of the steel 10 constituent remains along the weld boundary. Thus, the size of the weld zone decreases with an increase in the amount of strain. After the fourth pass, the weld zone is between the weld boundary and the hardened region steel 10 .

Fig. 1a shows the values of $\sigma_{0.2}$ depending on reduction, which were obtained in the tensile tests for single-layer steels 10 and $08 \mathrm{Cr} 18 \mathrm{Ni10Ti}$ and the bimetal " $08 \mathrm{Cr} 18 \mathrm{Ni} 10 \mathrm{Ti}$ steel 10". It is obvious from Fig. 1a that the value of the conventional yield strength of the initial bimetal is 1.9 times higher than those of its constituents. This is explained by the fact that a hardened weld zone is formed during EW.

The values of $\sigma_{0.2}$ increase with an increase in reduction for all the materials. The value of the conventional yield strength of $08 \mathrm{Cr} 18 \mathrm{Ni} 10 \mathrm{Ti}$ steel at a reduction of $30 \%$ has increased threefold in comparison with the initial state before rolling. With subsequent strain, the material is slightly hardened. The value of $\sigma_{0.2}$ for the bimetal after all rolling passes has increased by $35 \%$. The hardening is evenly distributed. For steel 10 , after a reduction of $23.6 \%$, a twofold increase in the value of $\sigma_{0.2}$ is observed, as compared to the initial state. Further, the hardening behavior is similar to that of the bimetal, but the values of $\sigma_{0.2}$ remain lower.

The values of $\sigma_{0.2}$ of the materials constituting the bimetal and the weld zone (see Fig. 1b) were defined using the method of kinetic indentation and the method reported in [5]. The data obtained for the bimetal materials according to the method discussed in [5] are close to those obtained during tension. This confirms the applicability of the technique described in $[5,6]$ to the determination of the mechanical properties of materials. The exception is $08 \mathrm{Cr} 18 \mathrm{Ni} 10 \mathrm{Ti}$ steel, for which the value of the conventional yield strength obtained by the procedure described in [5] is 1.5 times higher than the values obtained in tensile testing. Steels have an austenitic structure in the initial state; however, under

Table 1. The thickness $(t)$ of a bimetals and its separate layers, the total reduction of the strip and the layers after each reduction.

\begin{tabular}{|c|c|c|c|c|c|c|c|}
\hline Reduction, No & $t_{\text {bimetal }}, \mathrm{mm}$ & $\eta_{\Sigma}, \%$ & $t_{\text {08Cr18Ni10Ti }}, \mathrm{mm}$ & $\eta_{\text {08Cr18Ni10Ti}}, \%$ & $t_{\text {steel 10 }}, \mathrm{mm}$ & $\eta_{\text {steel 10 }}, \%$ & $t_{\text {weld zone }}, \mathrm{mm}$ \\
\hline 0 & 5.8 & - & 1.9 & - & 3.9 & - & 0.4 \\
\hline 1 & 4.88 & 15.9 & 1.81 & 4.7 & 3.07 & 37.3 & 0.4 \\
\hline 2 & 4.4 & 22.6 & 1.8 & 5.3 & 2.6 & 46.9 & 0.35 \\
\hline 3 & 3.97 & 31.6 & 1.59 & 16.3 & 2.38 & 51.4 & 0.3 \\
\hline 4 & 3.27 & 43.6 & 1.43 & 24.7 & 1.84 & 62.4 & 0.1 \\
\hline 5 & 2.96 & 49.0 & 1.18 & 37.9 & 1.78 & 63.7 & 0.1 \\
\hline
\end{tabular}


deformation, austenite changes into stronger strain-induced martensite. After EW, strain-induced martensite appears in 08Cr18Ni10Ti steel. Besides, two entirely different stressstrain patterns are observed under tension and indentation, namely, those of tension and compression, respectively. As a rule, the resistance of metals to compression is higher than their resistance to tension; therefore, the values obtained in these two types of testing differ.

After EW, the weld zone is the most stable region in the bimetal; however, its $\sigma_{0.2}$ value is $40 \mathrm{MPa}$ lower than for the bimetal. When comparing the values of the conventional yield strength of the bimetal and the weld zone at different degrees of reduction, it is seen that these values are fairly close, but $\sigma_{0.2}$ of the weld zone is lower. During the first three passes, the conventional yield strength of the weld zone increases to $680 \mathrm{MPa}$. Further, the mechanical properties of $08 \mathrm{Cr} 18 \mathrm{Ni10 \textrm {Ti }}$ steel after 3 passes $\left(\eta_{\Sigma}=31.6 \%\right)$ are aligned over the entire material volume up to the physical weld boundary. The weld zone is now considered to mean the area between the physical weld boundary and partially hardened steel 10. Therefore, the value of $\sigma_{0.2}$ after the third pass in the weld zone slightly decreases to $650 \mathrm{MPa}$.

Fig. S2 (Supplementary Information) shows an example of a "08Cr18Ni10Ti-steel 10" print in the weld zone of the bimetal. It is shown that part of the imprint is in the area of steel 10, the largest part of it being in the area of the stainless steel.

For the theoretical evaluation of the strength of multicomponent systems, usually the mixture rule is applied [12-13]; according to this rule, each constituent of the composite makes its contribution to some mechanical characteristic, which is proportional to the value of the considered characteristic for this constituent and the specific volume of the constituent in the composite. The simplest version is as follows [12]:

$$
\sigma_{0.2 c}=\sum_{n=1}^{m} \sigma_{0.2 n} V_{n},
$$

where $m$ is the number of constituents in the composite, $\sigma_{0.2 c}$ and $\sigma_{0.2 n}$ are the conventional yield strengths of the whole composite and each of the constituents, $V_{n}$ is the volume fraction of a constituent relative to the total volume of the composite. There are many variations of the rule (1). In particular, to describe the elastoplastic behavior of bilayer clad composites, the following formula [13] is used to determine the conventional yield strength of the composite:

$$
\sigma_{0.2 c}=\sigma_{b a s}\left[1-R\left(1-\frac{E_{c l}}{E_{b a s}} \cdot \frac{1-v_{b a s}}{1-v_{c l}}\right)\right],
$$

where $\sigma_{b a s}$ is the strength of the metal of the basic layer; $E_{c l}$ and $E_{b a s}$ are the elastic moduli of the cladding layer and the basis of the constituents, $v_{b a s}$ and $v_{c l}$ are Poisson's ratios; $R$ is the ratio of the thicknesses of the base and the entire composition.

When considering the " $08 \mathrm{Cr} 18 \mathrm{Ni} 10 \mathrm{Ti}$-steel 10 " bimetal, taking into account that the elastic module are $205 \mathrm{GPa}$ for 08Cr18Ni10Ti steel and $200 \mathrm{GPa}$ for steel 10 and the weld zone and that Poisson's ratio for metallic materials is 0.3 [4], the values of $\sigma_{0.2}$ were obtained by formulas (1) and (2), see Table 2. To calculate the conventional yield strength of the bimetal after EW and incremental rolling, the values of $\sigma_{0,2}$ obtained for initial and rolled single-layer steels 10 and 08Cr18Ni10Ti were used, see Fig. 1a.

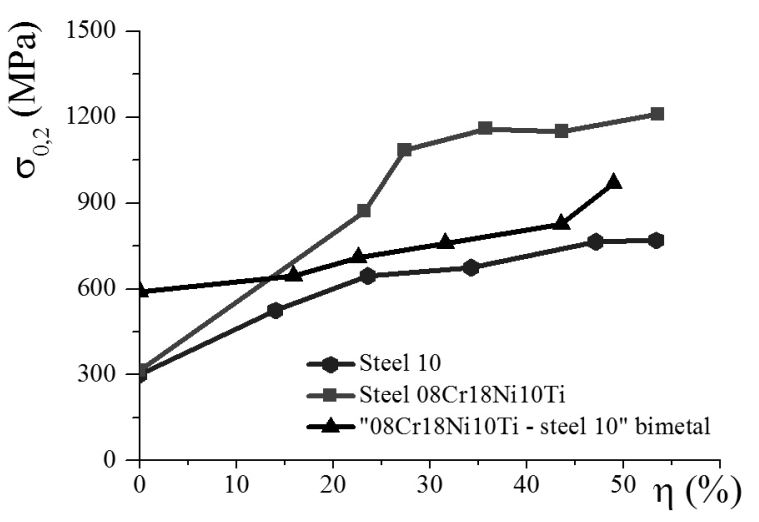

a

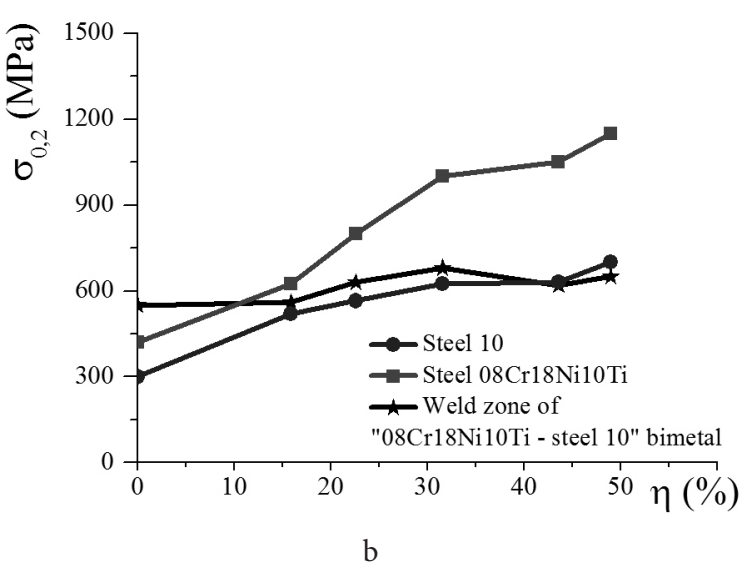

b

Fig. 1. The values of $\sigma_{02}$ as dependent on the reduction for the bimetal and single-layer steels 10 and $08 \mathrm{Cr} 18 \mathrm{Ni} 10 \mathrm{Ti}$, obtained under tension (a), and those for the separate parts constituting the bimetal, calculated by the method reported in [5] (b).

Table 2. Conventional yield strength of the "08Cr18Ni10Ti-steel 10" bimetal.

\begin{tabular}{|c|c|c|c|c|}
\hline Reduction, No & $\begin{array}{c}\text { Obtained in tension } \\
\text { testing, MPa }\end{array}$ & $\begin{array}{c}\text { Calculated by (1), } \\
\mathrm{MPa}\end{array}$ & $\begin{array}{c}\text { Calculated by (2), } \\
\mathrm{MPa}\end{array}$ & $\begin{array}{c}\text { Calculated by (1) with allowance made for the weld } \\
\text { zone and the properties calculated by the method } \\
\text { proposed in [5], MPa }\end{array}$ \\
\hline 0 & 590 & 305 & 305 & 336 \\
\hline 1 & 645 & 647 & 686 & 530 \\
\hline 2 & 710 & 698 & 776 & 617 \\
\hline 3 & 760 & 782 & 782 & 710 \\
\hline 4 & 825 & 908 & 781 & 813 \\
\hline 5 & 970 & 925 & 782 & 878 \\
\hline
\end{tabular}


The calculated values of $\sigma_{0.2}$ by formulas (1) and (2) for the bimetal after EW are almost half the values obt ained in the experiment. After the first pass of rolling, the values of $\sigma_{0.2}$ theoretically calculated by formula (1) are in the same range as those obtained experimentally. From the first to the fourth passes, the values calculated by formula (2) are close to the experimental ones, and they are $189 \mathrm{MPa}$ lower after the fifth pass. The difference between the experimental and calculated data for the materials after EW is attributable to the formation of a hardened weld zone during explosion welding. With the further plastic deformation, the constituents of the bimetal harden, the weld zone becomes smaller, and hence the mechanical characteristics obtained in experiments come into closer agreement with those obtained analytically.

We performed a separate calculation using formula (1), with the weld zone as a separate constituent, since we know its fraction and $\sigma_{0.2}$. The values of $\sigma_{0.2}$ obtained by the method proposed in [5] were used in the calculations for both steels studied. As a result, in view of the weld boundary, the calculated value of conventional yield strength for the bimetal is below the experimental values.

\section{Conclusions}

1. The strain of the layers of the bimetal is uneven during rolling. Initially, the least resistant material (steel 10) undergoes a higher strain. When this layer reaches the value of strain resistance of the second constituent (steel 08Cr18Ni10Ti), both layers are evenly strained. This conclusion concerns double-layer bimetals, and it may be not true for materials with a large number of layers.

2. The value of the conventional yield strength of the bimetal is slightly higher than that in the weld zone.

3. The thickness of the weld zone decreases with the increase in the amount of strain during rolling. Moreover, on the side of the $08 \mathrm{Cr} 18 \mathrm{Ni} 10 \mathrm{Ti}$ steel layer, the properties of steel and the weld zone tend to level off as number of passes increases, and they become the same when the reduction exceeds $49 \%$. For the weld zone on the side of steel 10, up to the maximum reduction, there is a weld zone, different in properties from steels 10 and $08 \mathrm{Cr} 18 \mathrm{Ni10 \textrm {Ti }}$.

4. The mixture rule can be used to calculate the theoretical conventional yield strength for the bimetal after explosion welding. However, the values obtained by the mixture rule are close to the experimental values only after additional plastic strain. After explosion welding, the theoretically calculated conventional yield strength parameter proves to be lower than the experimental one. This conclusion also applies to the case when the mechanical properties of the weld zone are taken into account.

5. The conventional yield strength value for the bimetal after explosion welding is higher than the values for each material individually. With further plastic strain, the strength properties of the stack increase less intensively than those of the stainless steel. This suggests that, in order to save expensive alloying components, the bimetal can be successfully used in mechanical engineering. In the case of a large additional plastic strain of the bimetal during production, its strength properties will be substantially lower than those of the stronger $08 \mathrm{Cr} 18 \mathrm{Ni} 10 \mathrm{Ti}$ stainless steel. This must be taken into account in the design and production of parts and structures.

Acknowledgements. We would like to thank Dr.D. Vichuzhanin, senior researcher, for assistance in tensile testing and I. Kamantsev, junior researcher, for help with rolling. This work was supported by project UB RAS No. 18-9-1-20.

Supplementary Information. The online version of this paper contains supplementary material (figures S1-S2) available free of charge at the journal's Web site (www.lettersonmaterials.com).

\section{References}

1. V.I. Lysak, S.V. Kuzmin. Explosion welding. Moscow, Mashinostroenie (2005) 543 p. (in Russian) [Лысак В.И., Кузьмин С. В. Сварка взрывом. Москва, Машиностроение (2005) 543 с.]

2. J. Wadsworth, D. R. Lesuer. Mater. Charact. 45, 289 (2000). DOI: 10.1007/s13632-016-0270-4

3. D.L. Olson, T.A. Siewert, S. Liu, G.R. Edwards. ASM Handbook: Volume 6: Welding, Brazing, and Soldering. Materials Park, Ohio, ASM International (1993) 1299 p.

4. D. Roylance. Mechanical Properties of Materials. Cambridge, MIT Press (2008) 128 p.

5. D.A. Konovalov, S. V. Smirnov, A.V. Konovalov. Russ. J. Nondestruct. 44(12), $847 \quad$ (2008). DOI: $10.1134 /$ S1061830908120073

6. D. A. Konovalov, I.A. Golubkova, S. V. Smirnov. Russ. J. Nondestruct. 47(12), $852 \quad$ (2011). DOI: $10.1134 /$ S1061830911120072

7. L.-J. Zhang, Q. Pei, J.-X. Zhang, Z.-Y. Bi, P.-C. Li. Mater. Des. 64, 462 (2014). DOI: 10.1016/j.matdes.2014.08.013

8. Y. Kaya, K. Nizamettin. Mater. Des. 52, 367 (2013). DOI: $10.1016 /$ j.matdes.2013.05.033

9. I. A. Veretennikova, D. A. Konovalov, S. V. Smirnov. AIP Conf. Proc.10, 040089-1 (2016). DOI: 10.1063/1.4967146

10. S. V. Smirnov, I. A. Veretennikova, D.I. Vichuzhanin, Computational Continuum Mechanics. 7, 398 (2014). (in Russian) [C.В. Смирнов, И.А. Веретенникова, Д.И. Вичужанин. Вычислительная механика сплошных сред. $7, \quad 398$ (2014).] DOI: 10.7242/1999-6691/2014.7.4.38

11. G.D. Lahoti, S.L. Semiatin. ASM Metals Hand Book Volume 14 - Forming and forging. Materials Park, Ohio, ASM International (1993) 2100 p.

12. Yu.P. Trykov, V.G. Shmorgun, L.M. Gurevich. Deformation of layered composites. Volgograd, VolGTU (2001) 242 р. (in Russian) [Ю. П. Трыков, В. Г. Шморгун, Л.М. Гуревич. Деформация слоистых композитов. Монография. Волгоград, ВолГТУ (2001) 242 с.]

13. D. M. Karpinos, L. I. Tuchinskiy, L. R. Vishnjakov. New composite materials. Kiev, Vishha Shk. (1977) 312 p. (in Russian) [Д.М. Карпинос, Л.И. Тучинский, Л.Р. Вишняков. Новые композиционные материалы. Киев, Вища шк. (1977) 312 с.] 